ISSN: 1641-4713; e-ISSN: 2081-1160

DOI: https://doi.org/10.36551/2081-1160.2020.26.245-264

\title{
Deinstitutionalization of beliefs and Corporate Social Responsibility: Between neo-Pentecostalism and spirituality
}

\author{
Desinstitucionalización de las creencias y Responsabilidad Social \\ Empresarial, entre el neopentecostalismo y la espiritualidad
}

\author{
Luis Donatello \\ National Council of Scientific and Technical Research (CONICET-CEIL), Argentina \\ University of Buenos Aires, Argentina \\ National University of Litoral, Argentina \\ ORCID iD: https://orcid.org/0000-0003-0580-8095 \\ E-mail: 1donatello@ceil-conicet.gob.ar \\ Virginia Galán \\ University of Buenos Aires, Argentina \\ ORCID iD: https://orcid.org/0000-0002-0989-1095 \\ E-mail: virgigalan@hotmail.com \\ Julia Evangelina Velisone \\ University of Buenos Aires, Argentina \\ ORCID iD: https://orcid.org/0000-0003-1770-9844 \\ E-mail: jvelisone@gmail.com
}

Recepción: 30.04.2020

Aprobación: 14.01.2021

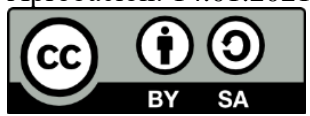

\begin{abstract}
This paper aims to explore the impact of certain recent transformations in the socioreligious field, in the economic and political spheres - more specifically, those derived from the processes of religious deinstitutionalization. For these, the current literature on the subject has elaborated at least two hypotheses: one characterizes the current scenario in terms of neo-Pentecostalization of the world, while the other is oriented more towards concepts such as spirituality. In this way, we concentrate on a case study that synthesizes the religious dimension with politics and economics: the field of Corporate Social Responsibility - CSR. In empirical terms, we set out to study the first International Congress of Social Responsibility (CIRS), which took place in October 2013
\end{abstract}


in Argentina. Two results can be highlighted from our study: on the one hand, CSR involves networks that express an area of social power that concentrates different resources. On the other hand, there is a range of values that go from spirituality to "NGO-ism", and that is characterized by different ways of collective construction centered on the individual as an agent of transformation.

Keywords: neo-Pentecostalization, spirituality, Corporate Social Responsibility, social power networks, politics of life, religious individualism.

Resumen: Este trabajo se propone explorar el impacto de ciertas transformaciones recientes en el terreno socio-religioso, en las esferas económica y política. Más específicamente, aquellas derivadas de los procesos de desinstitucionalización religiosa. Para ellas la literatura actual sobre el tema, ha elaborado - al menos - dos hipótesis: una que caracteriza el escenario actual en términos de neopentecostalización del mundo, mientras que otra se orienta más hacia conceptos como espiritualidad. De este modo, nos concentramos en un estudio de caso que reúne sintéticamente la dimensión religiosa con la política y la economía: el terreno de la Responsabilidad Social Empresarial-RSE. En términos empíricos, nos abocamos a estudiar el primer Congreso Internacional de Responsabilidad Social (CIRS), el cual tuvo lugar en octubre del año 2013 en Argentina. Dos resultados pueden destacarse de nuestro estudio: por un lado, en el terreno de la RSE intervienen redes que expresan un polo de poder social que concentra diferentes recursos. Por otro, que existe una gama de valores que va de la espiritualidad al ONGismo; y que se caracteriza por diversas maneras de construcción colectiva centrada en el individuo como agente de transformación.

Palabras clave: neopentecostalización, espiritualidad, Responsabilidad Social Empresarial, redes de poder social, política de la vida, individualismo religioso.

\section{INTRODUCTION: SOCIAL RESPONSIBILITY AND POLITICS OF LIFE. A QUALITATIVE STUDY OF SOCIAL NETWORKS}

Today, the religious field has been transformed and, therefore, so have the classic frameworks with which its links to other spheres such as politics or the economy were thought of. In this sense, a set of recent investigations shows that during the last decade in Argentina the percentage of people who consider themselves Catholic has decreased, while the percentage of Evangelicals, of people who identify with no religion and of those who claim to believe in representations such as divine energy has increased (Mallimaci et al., 2019). Other authors sustain that said changes obey to a visualization of a religious diversity hidden by state institutions, as well as to beliefs and practices that from the margins of the sacred are questioning the Catholic monopoly (Frigerio, 2007; Wright \& Ceriani, 2011). Regardless of such controversies, all these results speak to us of a process of deinstitutionalization of religious life. In this way, a central question is to what extent these transformations impact the aforementioned areas.

The classical way of treating this type of phenomena, starting from the typology constructed by Weber (1987), perfected by Troeltsch (1956), and then reviewed by the Sociology of Religion, was to refer to the category of mysticism. Fundamentally, this characterization emphasized that beliefs should be organized 
around individual choice, in opposition to both the Church model, understood as a form that represented society, and the sects, considered as small communities (Becker, 1932). This could lead both to the creation of new denominations or denominationalism, and to religious individualism, that is, the individual as the center of authority (Berger \& Luckmann, 1996; Niebhur, 1929). More recently, this topic has been studied by Campbell, who has emphasized the way in which certain mystic streams have functioned as a vehicle for oriental religions in the occidental world (Campbell, 1997).

Following these alternatives and thinking about current problems, at least two hypotheses are opened for the problem of the articulation between religion, politics and economy. On the one hand, following authors such as Pace (2017) or Michel (2017), we can resort to the complementary arguments that point to the break of the "Catholic hegemony" and the "Pentecostalization of the world" in Western countries. In other words, in face of the dissolution of the authority of the Catholic Church, denominations that follow the dynamics of the neo-Evangelical or Pentecostal churches are emerging. This, at the same time, implies affinities between theologies of prosperity, discourses of management and certain neoliberal currents. On the other hand, but also starting from the concept of mysticism, another path links free choice with spirituality (Hanegraaff, 2001; Heelas, 2010; Houtman \& Aupers, 2007). Focusing on the analysis of New Age currents, these studies analyze different approaches in relation to the previous argument. For them, the central feature of socio-religious transformations is that individuals become the center of authority and, therefore, the political and economic consequences are linked to what Giddens calls "politics of life" (Frigerio, 2016; Giddens, 1991).

Both hypotheses are not necessarily mutually exclusive. In studies of these phenomena in Latin America, we can find them overlapping. In that sense, in Argentina there are those who maintain that the advance and proliferation of spiritual practices and beliefs is developed in a context of rupture of the Catholic monopoly and pluralization of religious beliefs (Mallimaci \& Giménez Béliveau, 2007). There are authors who point out its advance in different social spaces, such as health (Bordes \& Saizar, 2018), mass media and cultural industries (Algranti, 2018; Semán, 2006), the business sphere (Funes, 2016), and politics (Viotti \& Funes, 2015). As Semán and Viotti (2015) show, the presence of New Age sensibilities in these different spaces expresses the end of what Carozzi (1999) called the "submerged network" in the 1980s and the emergence of a new stage characterized by a strong visibility of New Age practices in public space (Vargas \& Viotti, 2013; Viotti, 2015). 
Thus, we have recently come across lines of research in development that study the impact of these phenomena on politics and economy. There are works that analyze articulations between organizations linked to New Age religiosity and the governmental sphere (Viotti \& Funes, 2015), links between spirituality and the feminist movement (Felitti, 2019), and the impact of the transformation of beliefs in the debates around the policies on sexuality, drugs (Pecheny et al., 2016), and bioethics (Irrazabal, 2015). More recently, we found work that focuses on these links in areas such as science and social development policies (Donatello \& Nachón Ramírez, 2018) or in areas of Corporate Social Responsibility (Donatello et al., 2019).

Considering these references, in this article we propose to work on this last topic: Corporate Social Responsibility (CSR). This phenomenon can be understood in several ways. One of them is to refer to the organizational transformation frames as well as its emergence and diffusion in the context of the current transformations of capitalism, leading to management models and its professionalization within the corporate life (Powell \& DiMaggio, 1999). Another one is linked to what we could call "good practices", where the incorporation of ethical factors allows to increase profits (Kliksberg, 2011). It can also be considered as a part of the "managerial grammar" and, therefore, as a central value to develop a successful career (Luci, 2009). In addition, it can be considered as one of the great ideological constructs of current corporate capitalism (Boltanski \& Chiapello, 1999; Cavia, 2013).

From these different perspectives, we are interested in a unique aspect. Several agents that circulate around CSR configure networks where beliefs, the business world and politics are interwoven in a way that can provide clues as to how these links currently operate. In this way, our main objective will be to characterize them.

\section{THE CASE AND THE METHODS}

In this paper we study the first International Congress on Social Responsibility (Congreso Internacional de Responsabilidad Social, CIRS), which took place in October 2013 in Ciudad Evita, La Matanza, Buenos Aires Province. ${ }^{1}$

\footnotetext{
${ }^{1}$ Ciudad Evita was developed in 1947 during Perón's government with the aim of constructing social housing and consolidating the Peronist political project. The city name refers to María Eva Duarte de Perón, then wife of the president, and figure of great symbolic importance for Peronism until today. Also, it is believed that the aerial view of city limits draws the shape of her figure.
} 
Different actors from organizations belonging to diverse sectors of society, such as companies, civil society organizations, cooperatives, trade unions, universities, and state agencies at the national and international level participated in the Congress. This event had speakers like the Nobel Prize for Economics, Amartya Sen, the former president of Brazil, Luíz Inácio "Lula" da Silva, and the former Spanish president, Felipe González. As described on the CIRS 2013 website, the Congress proposed the meeting for "...updating an activation in the area of Social Responsibility. In this sense, it constituted a space for the exchange of experiences, new learning, research and good practices in this area. It included keynote speeches, plenary sessions, round tables, dialogues, workshops and exhibitions." "Some objectives of the Congress were to provide an annual meeting to "Share approaches, tools, cases and practices in Social Responsibility that different public and private organizations are executing or planning to execute; generate new channels of communication and foster relationships to form alliances between the different participating actors generating Social Capital; create the first Social Responsibility Fund, a financing mechanism to make investments with social impact that will constitute a clear tool for inclusion" (CIRS, 2013).

The congress was organized by the Social Responsibility Observatory Foundation (Fundación Observatorio de Responsabilidad Social, FORS), FONRES RSE ${ }^{3}$, the La Plata Regional Faculty of the National Technological University, and the Faculty of Economic Sciences of the University of Buenos Aires. It is important to highlight that FORS is a consulting space that was created to advise and communicate about Social Responsibility, working with companies, civil society organizations, unions, universities, cooperatives and the State. As it is argued on the website of FORS, its mission consists of analyzing, monitoring, and providing tools to reach consensus on Social Responsibility, while working with the following values: "Diversity, excellence, transparency, responsibility, efficiency and effectiveness" (FORS, 2020). ${ }^{4}$ The director of this foundation is Alessandra Minnicelli, lawyer and doctor in law (University of Buenos Aires), former head of the National Auditing Commission, and also wife of the former

\footnotetext{
2 Memory of the first International Congress of Social Responsibility (available at: http://www.cirs2013.com/porque.php), from which we review the section called "Experiences for economic and social responsibility" (pp. 33-38).

${ }^{3}$ FONRES RSE is a company specialized is Corporate Social Responsibility, providing technical assistance and consulting services (FONRES RSE, 2020).

${ }^{4}$ The observatory and the foundation have the objective of creating a space of observation and communication for RSE experiences, in coordination with universities, syndicates and civil organizations (FORS, 2020).
} 
Minister of Planning Julio de Vido (Lavieri, 2018). Far from being a minor fact, this reference leads us directly to the agents involved.

Taking this framework into account, we propose to concentrate on the presentations given at the section "Experiences for economic and social sustainability," given that in that part of the event the links between the dimensions that are of interest in this article are synthesized, namely beliefs, politics and economy in the field of Empresarial Social Responsibility (Responsabilidad Social Empresarial, RSE). In this way, we follow three complementary methodological strategies. Firstly, to characterize the public trajectories of the participants from secondary sources. From there, to reconstruct the social networks that these ones constitute. And, thirdly, to attempt a hermeneutic exercise of their interventions.

\section{THE AGENTS AND THEIR NETWORKS. BEYOND AND BEFORE LA GRIETA}

The different speakers were Pablo Vagliente, Andrés Freire, Juan Carlos Lascurain, Claudio Epelman and Virgilio Gregorini. It is interesting to observe how, only two years later, some of these people appeared in public as criminal suspects and protagonists of what was known in the media as La Grieta, that socially polarizes and politically divides Argentineans. La Grieta (the split) is a term used in Argentina to indicate the social and political division between the followers of the Kirchnerist governments (2003-2015) and their opposition, which was represented by Macri's government (2015-2019). This term not only represents a political differentiation accentuated since 2008, but also implies a fracture in Argentine society and in the mutually exclusive paradigms of thought. At this point, La Grieta comprises opposite constructions of the figures of citizenship, State and society, and is postulated as a barrier to the healing and growth of Argentina.

We would like to briefly comment on who these figures are and why they talked about this issue during the CIRS. First of all, Pablo Vagliente is the National Head of the Avina Foundation, of which he was a member from 2005 to the moment of the event. ${ }^{5}$ Fundación Avina is a Latin American foundation created in 1994, focused on producing large-scale changes for the sustainable development of the region by building collaborative processes between actors from different sectors to positively impact the Sustainable Development Objectives (Fundación Avina, 2020).

\footnotetext{
${ }^{5}$ Avina states that its history is in line with its compromise with social change in favor of sustainability (Fundación Avina, 2020).
} 
Secondly, Andrés Freire ${ }^{6}$ is the president of the Endeavor Foundation ${ }^{7}$ and Director of Trocafone ${ }^{8}$ since 2014. He is also a member of the Latin American Global Committee of the World Economic Forum ${ }^{9}$ and a member of the Global Advisory Council of the Harvard Business School. ${ }^{10}$ His career began in 1990 when he created the Initiative Foundation, then he was Financial Supervisor of Procter \& Gamble between 1993 and 1994, and co-founder of Officenet between 1996 and 2002. The latter company was bought by Staples in 2002, after which Andrés Freire co-founded and was CEO of Axialent between 2002 and 2011. He was subsequently co-founder and Director of Restorando.com between 2012 and 2015 and then founding partner of Quasar Builders between 2013 and 2015. He was also co-founder of Get Sirena, Avenida.com and Rodati.com. His career in the public sector began within the political party Propuesta Republicana (PRO $)^{11}$ in 2015 as Minister of Modernization, Innovation and Technology in the Government of the City of Buenos Aires until 2017, after which he became Legislator of the City of Buenos Aires for Vamos Juntos ${ }^{12}$ between December 2017 and June 2018. He also collaborated for 8 years as an "expert entrepreneur" on CNN en Español and is currently a weekly columnist on Telefe Noticias, on Telefe's AM program and on Perros de la Calle on Radio Metro 95.1. In addition, he founded and led the reality show El Emprendedor del Millón on Telefe. ${ }^{13}$

Thirdly, Juan Carlos Lascurain is the owner of the construction company Constructora Fainser S.A. since 2018. He started his career in the private sector in 1958 as a taxi driver, after which he worked at Adolfo Bullrich's estate agency. He later worked at M. Royo as a Deputy to the general management in 1968, a company of which he was Executive Director and partner in 2008. Regarding

\footnotetext{
${ }^{6}$ Data available at http://www.andyfreire.com/ and https://ar.linkedin.com/in/andyfreire.

${ }^{7}$ The Endeavor Foundation promotes entrepreneurial culture by providing strategic advice for highimpact businesses and improving their market presence (Endeavor Argentina, 2020).

${ }^{8}$ Trocafone is an online platform to commercialize technological items such as cell phones and tablets.

${ }^{9}$ The World Economic Forum is an international organization that promotes public-private partnership. The Forum engages the most important political, business, cultural and other leaders of society to shape global, regional and industry agendas (World Economic Forum, 2020).

${ }^{10}$ The Harvard Club in Argentina is a place for Harvard graduates to connect and maintain the bond between the University and Argentina (Harvard Club de Argentina, 2014).

${ }^{11}$ Propuesta Republicana is the party that brought Mauricio Macri into national government in 2015, setting itself as the opposition to Kirchnerism.

${ }^{12}$ Vamos Juntos is a political alliance between Propuesta Republicana and Coalición Cívica Radical.

${ }^{13}$ The mentioned media belong to the largest media business group in Argentina, Grupo Clarín. It began to be in opposition to the government of Cristina Fernández de Kirchner, between 2008 and 2009, due to conflicts with the agricultural sector and the enactment of the Audiovisual Communication Services Law No. 26,522.
} 
his career in the public sector, it began in the industrial unionism in 1975, and he was a representative in the Chamber of Sewage Manufacturers between 1983 and 1997 ${ }^{14}$. That year he was elected President of the Association of Metallurgical Industries (Asociación de Industriales Metalúrgicos, ADIMRA) until 2001. He was also President of the Association of Promotion "Friends of the City Garden of Lomas del Palomar" since 1999. Then he was Vice-President for Small and Medium-size Enterprises of the Argentine Industrial Union (Unión Industrial Argentina, UIA) since 2001. In 2007 he was once again elected President of ADMIRA until 2013 and was President of the UIA from 2008 to 2010. Recently, he became one of the defendants in several investigations regarding corruption in public works during the previous administration (Rebossio, 2008; Telam, 2018).

In fourth place, Claudio Epelman is the Executive Director of the Latin American Jewish Congress, and representative of the World Jewish Congress before the Holy See. ${ }^{15} \mathrm{He}$ is also a member of the Advisory Council of the King Abdullah Bin Abdulaziz International Centre for Interreligious and Intercultural Dialogue, Vienna, and a member of the International Advisory Committee of the Doha International Centre for Interreligious Dialogue, Qatar. In addition, he is the Vice Moderator of the Latin American Council of Religious Leaders of the World Conference of Religions for Peace, Co-Chairman of the Latin American branch of the Global Forum to Fight Anti-Semitism, and is a member of the advisory committee of the Secretariat of Programming for the Prevention of Drug Addiction and the Fight against Drug Trafficking of Argentina (Secretaría de Programación para la Prevención de la Drogadicción y la Lucha contra el Narcotráfico de la Argentina, SEDRONAR). For his work for dialogue and cooperation between different religious communities he was recognized by the Argentine government in 2007.

Finally, Virgilio Gregorini, ${ }^{16}$ who was born in 1980, was the Director and Representative of $\mathrm{TECHO}^{17}$ in Argentina since 2013. He started his professional career as a TPM Analyst in Production for the brewery Cervecería Quilmes

\footnotetext{
${ }^{14}$ In Argentina, trade unions have a "Peronist" tradition because of the political place that Perón gave to the workers movement during his first governments (1946-1955). Kirchnerism, on the other hand, is presented as part of Peronism, but has its own specificities due to the circumstances in which it has developed.

${ }^{15}$ The Latin American Jewish Congress is an international organization that represents Jewish communities in the region and acts as a diplomatic bond to governments (http://congresojudio.org/autoridad.php?id=16).

${ }^{16}$ Data available at https://ar.linkedin.com/in/virgilio-gregorini-3433b217.

${ }^{17}$ TECHO seeks to overcome the poverty situation of slum dwellers in 19 Latin American countries through joint action with volunteers and donors (TECHO, 2020).
} 
between 2005 and 2006, and later as a Commercial Planning Analyst for Nestle Waters between 2006 and 2007, and a Cold/Hot Machine Workshop Supervisor for the same company between 2007 and 2008. Between 2008 and 2010 he was Project Coordinator for the Institute of Energy and Sustainable Development (Instituto de Energía y Desarrollo Sustentable, IEDS). His work at TECHO began as a volunteer - he held the position of Work Control Coordinator for TECHO between 2008 and 2010. Later on, he became TECHO's General Manager in Córdoba in 2010 and was Regional Director between 2011 and 2012. As has been presented in other works, TECHO is an NGO related to Catholic circles (Donatello, 2008).

The brief description of the abovementioned trajectories allows us to understand the linkage of the speakers studied in this work, that is, to rebuild the networks and the resources they manage. In this sense, Epelman, as Executive Director of the Latin American Jewish Congress, and Gregorini, as Director of TECHO Argentina, present resources of symbolic power. Vagliente, as National Head of Avina Foundation, presents financial resources. Finally, Freire, as Director of Trocafone, and Lascurain, as Head of Fainser S.A., present material resources. These last two speakers also presented institutional resources throughout their careers, the first as an official of Propuesta Republicana (PRO), and the second as part of the industrial union leadership. Their articulation under the same congress and the same objective shows the links of the circles of power, from the amplitude of their resources to the complementarity of their motivations.

These aforementioned articulations between different sectors become more important in the context of societal changes on different levels of everyday life. The economic movements of this century, as well as the transformations in the political sphere, imply changes in the narratives and symbolic resources. In this sense, the articulation of those who hold economic corporate power, as well as those who are linked to the sphere of workers' representation, are joint thanks to the resources provided by those who direct the symbolic sphere. This change of narrative is presented as Corporate Social Responsibility, a title under which social problems are analyzed and their solutions are proposed under the previously mentioned articulation of power groups. Thus, the need for improvements by both religious representatives and representatives of NGOs is a condition for the possibility of accommodating the governing and business sectors to the present social changes. ${ }^{18}$

${ }^{18}$ During the government of Mauricio Macri (2015-2019) Corporate Social Responsibility upheld its importance. On April 20, 2017, an event named El compromiso empresarial: de la responsabilidad social empresarial a la agenda 2030 ("The corporate compromise: from corporate social 


\section{THE REPRESENTATIONS: FROM SPIRITUALITY TO "NGO-ISM"}

Firstly, we comment on the content of the papers presented by the previously mentioned figures. It is common knowledge that in the global context there are inequalities of various kinds (economic, political, social, etc.) that need to be dealt with. Sustainability or sustainable development is a term that appears throughout numerous papers, and which represents the path to fix the inequalities that are being experienced nowadays. Sustainability is understood as the capacity to be sustainable, that is, to make conscious and responsible use of economic and environmental resources. While analyzing these CIRS presentations, we find different types of figures that deal with the main subject that names the congress. These are different actors talking about their experiences on economic and social sustainability, various forms and proposals to deal with inequalities, ways to generate productive development for the country, and the creation of a new political and social context that can tackle the existing crises.

As we have mentioned before, sustainability, as well as the possible solutions for the existing inequalities in Argentina and the world, are the topics dealt with in several of the presentations. However, we will analyze the readings and interpretations that were made in the parallel session which vary among the different subjects.

\section{Pablo Vagliente: sustainability as a spiritual phenomenon}

Reading the papers presented during the CIRS leads us to different views on the topics that are being analyzed. As we begin with Pablo Vagliente, we find ourselves faced with an approach regarding sustainability that we will call "spiritual”. This is understood as something integral: “(...) there is no social sustainability without the environmental, the economic and I would say, also, without the cultural and the spiritual" (Minicelli \& Jasler, 2014, p. 94). ${ }^{19}$

Those factors must be included to be able to carry out a sustainable development that breaks with the lack of sustainability, that is to say, with the

\footnotetext{
responsibility to the 2030 agenda") took place at Casa Rosada (seat of the Executive Power of the Argentine Republic, located in the central area of the Autonomous City of Buenos Aires). In this case, the networks between different sectors in the development of the topic of CSR are also present. We can highlight the continuity of articulation between local and international government sectors, religious sectors and participants in forms of social volunteering.

${ }^{19}$ This and all the subsequent fragments cited from the Memoir of the Social Responsibility Congress (Minicelli \& Jasler, 2014) are our own translation from the Spanish original.
} 
inequalities. Also, Vagliente stresses that these problems come from the lack of "values that guide the action" (Minicelli \& Jasler, 2014, p. 95). This refers to the lack of values and regulations that control a capitalist system that generates all types of inequalities: "A second drawback is that, perhaps, in sustainable development power is rarely questioned. But, in order to change things and abandon a certain paradigm to move on to a truly sustainable one, we must also ask ourselves about the conditions in which power is generated or a dispute for power is established, so that, with our proposal and our force for change, we can gradually impose conditions. That is central in the issue of sustainable development" (Minicelli \& Jasler, 2014, p. 94).

The emphasis on the individual dimension as a transforming tool is something that usually appears in other presentations. In this sense, the phenomenon of inequality is perceived along the implication that these forms of collective action have, above all, personal intimacy as their focus.

Beyond the religious experience, we find a particular link between Pablo Vagliente's approach to sustainability and spirituality, where the various actors are responsible for being able to carry out sustainable development: "In Avina we like to talk about cause economics as a way of spinning or linking, how the economy itself can be part of cause movements that link producers and consumers who have important decision-making power. Because their decisions weigh on this way of understanding the economy and its social and environmental aspect" (Minicelli \& Jasler, 2014, p. 95).

This link is also part of a long tradition that emphasizes, from different mystic streams, the harmony between the subject, its environment and nature, in opposition to its subordination to the scientific and technological development that constituted a feature of the industrial modernity of the 19th and 20th centuries.

\section{Andy Freire: the selfless action}

In line with what has been outlined above, Andy Freire's paper emphasizes individual responsibility. From the outset, the speaker presents himself as someone committed to making the world a better place, as well as passing on that commitment to others. In this way, he presents us with his successful entrepreneurial story. But he does not fail to mention that the economic success he achieved with his ventures did not imply any personal satisfaction: "I had done well, I had sold the company, but deep in my heart I was just as empty as before" (Minicelli \& Jasler, 2014, p. 98). 
We can analyze this in line with the above, as a manifestation of a type of mystical spirituality that presents salvation or self-realization of the self as an individual task. However, it is important to note that in this case individual salvation goes hand in hand with helping others, but not from an economic perspective, since it is not about giving money to those who need it most. It is about helping others throughout commitment and devoting time.

Freire argues that the benefits of doing this type of action are extensive: "...doing things for others reduces cardiovascular risk in the same way or even more than quitting smoking. The fact that you are actively helping others in terms of the impact on stress and the cardiovascular system is impressive" (Minicelli \& Jasler, 2014, p. 98). Helping others, doing things for others, has benefits for all people regardless of their socioeconomic level: “(...) deep down, doing things for others makes you happier" (Minicelli \& Jasler, 2014, p. 99).

In his paper, Andy Freire often refers to how giving 5\% of the time one has to help another can not only change that other person's life but, as we have just mentioned, one's own. He makes it clear that "to change the life of another, you don't have to be Mother Teresa of Calcutta and spend $100 \%$ of your time helping. Only 5\% is needed, and the sum of each individual's willingness to devote that time can make enormous changes for the world: ending illiteracy, building homes, etc.; as well as changes for oneself: personal fulfillment, happiness" (Minicelli \& Jasler, 2014, p. 101).

This topic, in fact, refers us to the basis of philosophical utilitarianism and its particular way of understanding the tension between selfishness and altruism. That is to say, the paradox according to which the individual action can generate solidarity. But, with the variant of philanthropy, what can be called "selfish" could easily be "altruistic" in the way that the individual can start from a selfless decision: "When they ask me what they did with the money, I always answer that it does not matter where we placed it. What matters is what each of us can do with $5 \%$ of our time for the other. I believe that with that $5 \%$ you can change $100 \%$ the life of another who needs it. And it's not about giving what you have to spare" (Minicelli \& Jasler, 2014, p. 101). In line with what has been presented in this article, those who have worked in the New Age movement have illustrated this ethic on a global level as well as locally (Semán \& Viotti, 2015; Vargas \& Viotti, 2013; Viotti \& Funes, 2015). In this sense, the previous paragraph shows synthetically a central element referred to the subject's affirmation towards the emancipatory traditions in the collective dimension. 


\section{Claudio Epelman: from Latin pietas to Jewish Tzedakah}

Claudio Epelman illustrates in quite a synthetic way the transcendent bases of this type of conception. Its foundation, unavoidable in the Greco-Latin culture, is the notion of pietas: a call to the ethical and transcendent sense of human action (Wagenvoort, 1980, pp. 7-12). In Jewish theology, it can refer to the term tzedakah: "This has much to do with the theme of religion, tradition, social responsibility. In this example we find the message of the construction of an ethic and a system of values that allow us, as a society, to be able to understand the responsibility that those who have more owe to those who have less. Judaism calls for the construction of social justice in a concept we call tzedakah, which we often translate as 'charity'. However, this has an even deeper meaning: whoever has goods is not the absolute owner of everything he has, a part of it belongs to others. So, when one gives, one is not giving of one's own, but is giving back to society what one possesses without being an owner" (Minicelli \& Jasler, 2014, pp. 105-106).

This moral imperative, which submits the individual decision to a broader whole, also refers us to an argument that has an eschatological horizon: "There appears in our tradition the concept of repairing the world, what we call in Hebrew the tikkun olam: to repair the world means to finish creating it. The world was created with some inequities. It is our responsibility to try to overcome them and make a more just and united world, which we all want and desire. (...) From the Jewish tradition we can find elements that have a lot of validity, a common denominator, social sense. It can be summed up in something that, without a doubt, is the essence of Jewish tradition. But it is also the essence of each of the religious traditions. Probably the ethical messages, as the denominator of religious congregations, are the possibility that we have to contribute to the world of business, university and civil society with the notion of a more just and supportive world" (Minicelli \& Jasler, 2014, p.106).

It is remarkable how this eschatological construction includes a set of collectives and organizations that are considered as belonging to "civil society": religious "congregations", the company, the university. That is, all spaces for individual action, with a great absentee: the State.

\section{Virgilio Gregorini: the self-sustaining community}

As we stated before, the utilitarian argument has different transcendent foundations. In the context of reference, we saw one that is referred to in the Jewish tradition and in inter-religious dialogue. However, it is complemented by 
the idea of individual action as the thrust of social transformation, especially when the State is deliberately omitted. This type of utopian construction is very well suited to another foundation. We can identify it with an ancient principle of Catholic theology: subsidiarity. It refers to a conception that starts from a base: communities regulate themselves, without the need for State authorities. These can only subsidize.

Virgilio Gregorini puts it in the following terms: "Communities do not need us to tell them what they have to do to improve their quality of life, they only need us to listen to them and to bring them tools. The only sustainable way to solve multiple problems in the settlements is by listening to the people who suffer from them. Not only do they have the capacity to know what their problems are, but they also know what needs to be done to overcome them (...) It is not only a matter of preserving life and deploying it in a sustainable manner, but also of effectively accessing the right conditions for autonomy, integration and human fulfillment" (Minicelli \& Jasler, 2014, pp. 109-110).

This way of approaching utopian construction, which - as we pointed out has a long tradition in the Catholic world, can be called "communitarian" or "communitarist". We can find it in the political experiences of Argentina in the 20th century (Giorgi, 2015), from authoritarian and dictatorial projects to this current forum that was facilitated by a government self-referred as "National and Popular".

\section{The exception: Juan Carlos Lascurain, "Pymism"}

The exception, and counterpoint, to the previous emerging topics can be found in Juan Carlos Lascurain's presentation. It emphasizes the role of the State in the development and growth of Small and Medium-size enterprises, which have a great influence on the growth of regional economies and the elimination of social inequalities.

Lascurain points out that: "The experiences of economic and social sustainability have two actors, two main responsible parties: one is the State and its economic policies and the other are the entrepreneurs" (Minicelli \& Jasler, 2014, p. 104). Regardless of the veracity of this statement, the reference clearly establishes a confrontation in relation to the emerging topics of the previous interventions. Lascurain invokes in a simple formula the opposition to the axiological guidelines that emphasize individuals, communities and an organizational world-

20 "Pymism" refers to Small and Medium-size Enterprises and comes from the Spanish term Pequeñas y Medianas Empresas, or PyMEs. 
view centered on a concern for recent transformations: the twentieth-century corporatism and its association to the State, the employers' chambers and the unions, represented by Lascurain in the metal industry. In addition to the parity regulation between these three vertices as a model of negotiation and centralization, and verticality in productive relations, these are all elements that emerge from this statement.

Recovering the polysemy of the term "corporation", here the counterpoint could be established between the old corporate capitalism of the 20th century versus the new corporate capitalism of the 21 st century. The business chambers, the unions and the State anchored in national societies versus the large global economic conglomerates. Or, in Giddens' terms, the "old politics" versus the "politics of life".

\section{CONCLUSIONS}

In this article, we began with the question of how transformations in the religious field impact the political and economic spheres. Our aim was to characterize possible links between these dimensions. To do so, we used a case study within the field of CSR in present-day Argentina. In that sense, it would be a mistake to start from what could be the conclusion of our investigation: that in the world of CSR the relationship between beliefs and politics is between "spiritualities" and "politics of life" recovering - once again - the already old works of Giddens.

On the contrary, if we focus on the networks and the topics that emerge from the theoretical elaborations, we have abundant data to deepen our investigation. By reconstructing the conceptual chain, we have seen that the theme of sustainability emerges, associated with a conception that emphasizes individual transformation. In this sense, its impact can be synthesized in what we could call "altruistic selfishness". These three elements have a theological-philosophical basis in the commitment to inter-religious dialogue and communitarianism. None of this is new, not even original. On the contrary, these are debates that in other latitudes - e.g., the United States - have been taking place since the 1980s (Arato \& Cohen, 1992, pp. 53-112).

What is singular is that this conceptual map is manifested in an event organized by a government that was - from the surface of political analysis posed as the opposite. We can judge and label as we want the Latin American political experiences between 2002 and 2015-2016: center-left governments, neo-developmentalists, Latin American populisms, to mention the terms usually 
invoked. In that sense, each national experience had its distinctive features. Perhaps the Kirchnerist government in Argentina could be considered as a bet for the strengthening of the state against the big transnational corporations, the vindication of the 1970s political involvement, the alignment against the FTAA in the regional level, to mention some characteristics. However, this type of event shows us something else. In the first place, a political, business and religious network of people strategically located at the moment of taking decisions. Secondly, a set of presentations with an important degree of sophistication in their preparation that tell us something different from what is preached in superficial political analysis. That is the continuity between things that happened in 2013 and today, and, therefore, in between opposed governments and political parties.

In other words, if we ask ourselves what the conceptual map we have just characterized could mean in 2013, we have a bet sponsored by the government of that time. This position, which we can closely link to a set of diagnoses and tensions already classic within the liberal thought, could be linked to something that was already happening in other countries of the region with governments of the same sign: to generate confidence in the large multinational corporations to overcome the economic stagnation that was approaching. Now, if we go to the trajectories and networks of the people involved, we find another factor to take into account. As we said, it is a political, business and religious network with a degree of specialization in the subject it has been developing for decades. Far from any conspiracy or cynical perspective, we can understand such a plot within the framework of a set of transformations in current capitalism. In that sense, the hypothesis about the continuity between what happened in 2013 and what happens today is not necessarily an expression of a strategic decision or of a class consciousness that manipulates things and words. On the contrary, it seems rather the effect of a transformation in the level of relations in the world of big business and, at the same time, of social relations in general.

Considering this characterization, and the two positions raised at the beginning, we can then take a stand on the second working hypothesis. Rather than neo-Pentecostalisation, the term "intramundane spirituality" seems to be a much more appropriate tool for characterizing both the social fabric and the representations that emerge as significant from the studied interventions. This is due to the fact that they express a plurality that, far from referring to a certain business mysticism, is linked to a plurality of alternatives where, effectively, the individual capacity to transform the world is emphasized. 
In this sense, the link between neo-Pentecostalism and neoliberalism, which had the teleology of prosperity as thrust (Garrard-Burnett, 2011), doesn't appear as something significant in the ground that we have researched. On the contrary, sustainability, the selfless action, tzedakah -to mention the innovative emerging representations of the studied interventions - link a lot more to what we have named "intramundane spirituality".

\section{REFERENCES}

Algranti, J. (2018). Objetos en acción Estudio sobre instituciones, consumo y cultura material en el neo-pentecostalismo argentino. Estudios Sociológicos, 36(107), 393-416. https://doi.org/10.24201/es.2018v36n107.1538

Arato, A., \& Cohen, J. (1992). Teoría política y sociedad civil. Fondo de Cultura Económica.

Becker, H. (1932). The development and interaction of the ecclesia, the sect, the denomination, and the cult as illustrative of the dilemma of the church. In H. Becker \& L. von Wiese (Eds.), Systematic Sociology (pp. 613-642). John Wiley \& Sons.

Berger, P., \& Luckmann, T. (1996). La construcción social de la realidad. Amorrortu.

Boltanski, L., \& Chiapello, E. (1999). El nuevo espíritu del capitalismo. Akal.

Bordes, M. \& Saizar, M. (2018). De esto mejor ni hablar: omisiones y reformulaciones de lo sagrado por parte de terapeutas alternativos que trabajan en contextos hospitalarios. Sociedad y Religión, 28(50), 161-182.

Campbell, C. (1997). A orientalização do ocidente: reflexões sobre uma nova teodicéia para um novo milênio. Religião e Sociedade, 18(1), 5-22.

Carozzi, M. J. (1999). La autonomía como religión: La nueva era. Alteridades, 9(18), 19-38.

Cavia, M. (2013). La responsabilidad social empresaria en el discurso de diferentes instituciones y actores sociales. La Hendija.

CIRS (Congreso Internacional de Responsabilidad Social). (2013). Congreso Internacional de Responsabilidad Social 2013. http://www.cirs2013.com/porque.php

Donatello, L. (2008). Catolicismo y racionalidad económica. Trabajo, Ascetismo y Comunitarismo. Caminhos, Revista de Ciências da Religião, 5(2), 347-359.

Donatello, L. \& Nachón Ramírez, M. (2018, December 5-7). Afinidades electivas entre espiritualidades intramundanas y políticas de la vida. Dos estudios de caso en los ámbitos de Ciencia y Tecnología y Desarrollo Social [Conference presentation]. X Jornadas de Sociología de la Universidad Nacional de La Plata, La Plata, Argentina.

Donatello, L., Velisone, J. E., \& Galán, V. (2019, March 17-19). Responsabilidad Social Empresarial y Políticas de la vida. Un abordaje cualitativo de redes sociales [Conference presentation]. II Jornadas de sociología de la Universidad Nacional de Mar del Plata, Mar del Plata, Argentina.

Endeavor Argentina. (2020). Nuestra organización | Endeavor Argentina. https://www.endeavor.org.ar/nuestra-organizacion/\# 
Felitti, K. (2019). The spiritual is political. Feminisms and Women's Spirituality in Contemporary Argentina. Religion and Gender, 9(2), 194-214. https://doi.org/10.1163/1878541700902010

FONRES RSE. (2020). Inicio | FONRES. https://www.fonres.com/

FORS (Fundación Observatorio de Responsabilidad Social). (2020). Fundación Observatorio de Responsabilidad Social. https://www.ors.org.ar/

Frigerio, A. (2007). Repensando el monopolio religioso del catolicismo en la Argentina. In M. J. Carozzi \& C. Ceriani Cernadas (Eds.), Ciencias Sociales y religión en América Latina. Perspectivas en debate (pp. 87-116). Biblos. https://doi.org/10.22456/1982-2650.67123

Frigerio, A. (2016). La ¿"nueva"? espiritualidad: Ontología, epistemología y sociología de un concepto controvertido. Ciencias Sociais e Religiao, (18), 209-231.

Fundación Avina. (2020). STAFF - Fundación Avina. https://www.avina.net/en/staff/

Funes, M. E. (2016). La integración entre la espiritualidad Nueva Era y el nuevo management en Argentina: afinidades y tensiones. Ciencias Sociales y Religión, 18(24), 191-208. https://doi.org/10.22456/1982-2650.63585

Garrard-Burnett, V. (2011). A vida abundante: A Teologia da Prosperidade na América Latina. Historia: Questões \& Debates, (55), 177-194.

Giddens, A. (1991). Modernidad e identidad del yo. El yo y la sociedad en la época contemporánea. Península.

Giorgi, G. (2015). En los pliegues de la planificación del Onganiato: El comunitarismo como política estatal (1966-1970), Anuario IEHS, (29-30), 159-175.

Hanegraaff, W. J. (2001). Beyond the Yates Paradigm: The Study of Western Esotericism between Counterculture and New Complexity. Aries, 1(1), 5-37. https://doi.org/10.1163/157005901X00020

Harvard Club de Argentina. (2014). Desayuno con Andy Freire. Harvard Club de Argentina. http://hcargentina.clubs.harvard.edu/article.html?aid=272

Heelas, P. (2010). Spirituality in the modern world. Within religious tradition and beyond. Routledge.

Houtman, D., \& Aupers, S. (2007). The spiritual turn and the decline of tradition: The spread of post-Christian spirituality in 14 Western countries 1981-2000. Journal for the Scientific Study of Religion, 46(3), 305-320. https://doi.org/10.1111/j.1468-5906.2007.00360.x

Irrazabal, G. (2015). Religión y salud: la intervención pública de agentes religiosos formados en bioética en el debate parlamentario sobre la muerte digna en la Argentina. Salud Colectiva, 11(3), 331-349. https://doi.org/10.18294/sc.2015.720

Kliksberg, B. (2011). Escándalos éticos. Editorial Temas. https://doi.org/10.31876/revista.v3i5.8868

Lavieri, O. (2018, June 29). Alessandra Minnicelli, esposa de Julio De Vido, denunció al ministro Javier Iguacel por lavado de dinero. Infobae. https://www.infobae.com/politica/2018/06/29/alessandra-minnicelli-esposa-de-julio-de-vido-denuncio-al-ministro-javier-iguacel-por-lavado-de-dinero/ 
Luci, F. (2009). Aprender a liderar: los MBA y el reclutamiento de las Escuelas de Negocios en Buenos Aires. Notas etnográficas sobre el mundo del management. Revista de Antropología Social, (18), 317-337.

Mallimaci, F., \& Giménez Beliveau, V. (2007). Creencias e increencia en el Cono Sur de América: Entre la religiosidad difusa, la pluralización del campo religioso y las relaciones con lo público y lo político. Revista Argentina de Sociología, 5(9), 44-63.

Mallimaci, F., Giménez Béliveau, V., Esquivel, J. C., \& Irrazábal, G. (2019). Sociedad y Religión en Movimiento. Segunda Encuesta Nacional sobre Creencias y Actitudes Religiosas en la Argentina (Informe de Investigación, no. 25). CEIL-CONICET.

Michel, P. (2017). Contribution to a Socio-History of the Relations Between "Nation" and "Religion": The Case of Catholicism. In P. Michel, A. Possamai \& B. Turner (Eds.), Religions, Nations, and Transnationalism in Multiple Modernities (pp. 19-36). Palgrave McMillan. https://doi.org/10.1057/978-1-137-58011-5_2

Minnicelli, A., \& Jasler. V. (2014). Memoria 1er. Congreso Internacional de Responsabilidad Social. Fundación Observatorio de Responsabilidad Social.

Niebhur, R. (1929). The social sources of denominationalism. Holt.

Pace, E. (2017). Charisma as a Transnational Enterprise. In P. Michel, A. Possamai \& B. Turner (Eds.), Religions, Nations, and Transnationalism in Multiple Modernities (pp. 85-105). Palgrave McMillan. https://doi.org/10.1057/978-1-137-58011-5_5

Pecheny, M., Jones, D., \& Ariza, L. (2016). Sexual Politics and Religious Actors in Argentina. Religion and Gender. 6(2), 205-225. https://doi.org/10.18352/rg.10155

Powel, W., \& DiMaggio, P. (1999). El nuevo institucionalismo en el análisis organizacional. Fondo de Cultura Económica.

Rebossio, A. (2008, February 24). Perfiles. Juan Carlos Lascurain: desarrollista, concertador y con sintonía K. La Nación. https://www.lanacion.com.ar/989908-juan-carlos-lascurain-desarrollista-concertador-y-con-sintonia-k

Semán, P. (2006). Bajo continuo. Exploraciones descentradas sobre cultura popular y masiva. Gorla.

Semán, P., \& Viotti, N. (2015). El paraíso está dentro de nosotros. Nueva Sociedad, (260), 81-94.

TECHO. (2020). ¿Qué es TECHO? TECHO. https://www.techo.org/techo/

Telam. (2018, March 6). ¿Quién es Juan Carlos Lascurain? Telam. https://www.telam.com.ar/notas/201803/256962-quien-es-juan-carlos-lascurain.html

Troeltsch, E. (1956). The social teaching of the Christian Churches. George Allen and Unwin.

Vargas, P., \& Viotti, N. (2013). "Prosperidad y Espiritualidad para todos": Un análisis sobre la noción de emprendedor de eventos masivos de Buenos Aires. Horizontes Antropológicos, 19(40), 343-364. https://doi.org/10.1590/S0104-71832013000200013

Viotti, N., \& Funes, M. E. (2015). La política de la Nueva Era: El Arte de Vivir en Argentina. Debates Do Ner, (2), 17-36. https://doi.org/10.22456/1982-8136.61266

Wagenvoort, H. (1980) Pietas: Selected studies in Roman religion. Brill. https://doi.org/10.1163/9789004296688

Weber, M. (1987). Ensayos sobre sociología de la religión. Taurus. 
World Economic Forum. (2020). Our Mission. World Economic Forum. https://www.weforum.org/about/world-economic-forum

Wright, P., \& Ceriani, C. (2011). Modernidades periféricas y paradojas de la cultura: debates y agendas en la antropología de la religión. In M. Ceva \& C. Touris (Eds.), Nuevos aportes a los estudios de la religión en las sociedades contemporáneas del Cono Sur (pp. 147-164). Lumiere. 